\title{
Women's Economic Standing, Marriage Timing, and Cross-National Contexts of Gender
}

Proponents of the theory of specialization and exchange hypothesize that in any national context, women's higher economic standing will decrease their chance of marriage. Some researchers suggest, however, that only in industrialized countries with a high degree of role differentiation by gender does the inverse relationship between women's economic standing and the chance of marriage exist. To evaluate contrasting cross-national predictions, I test with longitudinal data and standardized methods whether the inverse relationship exists in 3 similarly affluent industrialized countries that vary in their degree of role differentiation by gender: the United States, Japan (a context more differentiated by gender than the United States), and Sweden (a context less differentiated by gender than the United States). Contrary to the prediction that develops out of the theory of specialization and exchange, results indicate that women's higher levels of income discourage first marriage formation in Japan, but encourage it in the United States and Sweden.

Does the expanding economic role of women weaken the institution of marriage in all contexts or only in contexts where men's and women's roles are highly differentiated? Although this is-

Institute for Social Research, 426 Thompson Street, University of Michigan, Ann Arbor, MI 48106 (hono@isr. umich.edu).

Key Words: cross-national, gender, income, marriage. sue has received some attention in analyses of a single industrialized country (e.g., South, 2001; Sweeney, 2002), it has received limited attention cross-nationally among industrialized countries. In this study, I investigate whether an inverse relationship between women's economic standing (as measured by income) and marriage timing (as measured by the chance of first marriage in a time interval) is present in all national contexts (i.e., the universality hypothesis) or only in national contexts with a relatively high degree of role differentiation by gender (i.e., the gendercontextual variation hypothesis). This is the first study to evaluate systematically the competing hypotheses cross-nationally. The cross-national framework permits a more general test of the hypotheses by allowing the inclusion of a broad range of contexts of gendered role differentiation. Such a range is difficult to obtain, even over a few decades, within a single industrialized country because of constraints imposed by cultural homogeneity. Three countries (Japan, the United States, and Sweden) are selected for analysis because (a) they occupy contrasting points on a continuum of role differentiation by gender, even though they are similarly affluent (Norris \& Inglehart, 2000), and (b) they have collected relevant nationally representative panel data. I apply standardized methods with appropriate controls to three panel data sets: the Panel Study of Income Dynamics of the United States (PSID), 1990-1997; the Japanese Panel Survey on Consumers (JPSC), 1993-1997; and the Swedish Household Market and Nonmarket Activity (SHMNA), 1993-1996. 


\section{BACKGROUND}

\section{The Hypotheses}

Leading theories of marriage formation are built on the view that men and women marry when they are better off doing so than remaining single (e.g., Becker, 1981). Although these theories commonly suggest that women's economic resources alter the costs and benefits of entering marriage for individuals, they differ on how the resources alter the costs and benefits.

The universality hypothesis, implied by the theory of specialization and exchange (e.g., Becker, 1981), is the prediction that, in all contexts, women with a higher (current) economic standing will delay marriage formation. The proponents of this theory argue that nonspecialized division of labor within a family, as indicated in part by a greater availability of women's economic resources, is not as efficient as a specialized division of labor, in which men work in the labor market and women work in the home (see Oppenheimer, 1997). According to this theory, the inefficiency creates disincentives that prevent women with higher economic standing from entering marriage (at a given time).

An alternative to the universality hypothesis is the gender-contextual variation hypothesis, which suggests that women's higher economic standing decreases marriage in countries with a relatively high degree of role differentiation by gender but encourages marriage in countries with more egalitarian gendered roles. A high degree of role differentiation by gender may persist in an industrialized country as a product of its historical, cultural, and ideological conditions (Leslie \& McGee, 2000) and may be sustained in part by its favorable aggregate economic condition (Oppenheimer, 1988). In such a setting, individuals and organizations typically operate under the assumption that men engage in full-time labor market work and women engage in full-time housework. The assumption induces stresses and inefficiencies in the lives of women who make economic contributions that discourage them and their partners from forming a marriage (Blossfeld, 1995; Mosesdottir, 2000). Such stresses and inefficiencies include engaging in the "second shift" (Hochschild, 1989) and being excluded from attractive job opportunities (Treiman \& Hartmann, 1981), which produces stress that spills over into marital relations (Conger et al., 1990). In contrast, among industrialized countries that are relatively egali- tarian (e.g., a context that is sufficiently attractive for the majority of wives to work), norms and practices in marriage and at work are more compatible with women's economic contribution and hence yield fewer stresses and inefficiencies (South, 2001). In such countries, both men and women are positively evaluated in the marriage market on their ability to make economic contributions (Sweeney, 2002).

Recent and contemporary results from industrialized countries, although fragmented and hence only suggestive, provide reasons to suspect that the pattern stated in the contextual variation hypothesis may be present. Cross-sectional and aggregate level findings from Japan (Atoh, 1994; Raymo, 1998) and Italy (Pinelli \& De Rose, 1995), which are countries with a relatively high degree of gendered role differentiation (Norris \& Inglehart, 2000), show that higher income levels of women (or higher educational levels as their proxy) are correlated with a lower rate of marriage. More reliable results from longitudinal or retrospective life history data indicate that, in more egalitarian settings, such as the United States (Lichter, McLaughlin, Kephart, \& Landry, 1992; Sweeney, 2002), Sweden (Bracher \& Santow, 1998), and Australia (Santow \& Bracher, 1994), higher levels of women's earnings are linked to a greater chance of first marriage at a given time. Before concluding that the contextual variation hypothesis is supported, however, a systematic analysis with standardized methods and individual-level longitudinal data is needed. The pattern in the existing literature may simply reflect major discrepancies in analytical designs across studies or major methodological limitations within a study (e.g., inadequate controls and simultaneous causality problems).

\section{Japan, the United States, and Sweden as Contexts of Gender}

Japanese, Americans, and Swedes vary substantially in the degree to which they assign work and family roles to a specific gender, as reflected consistently in attitudinal and behavioral data. Specifically, Japanese are the most likely to assign labor market work to men and housework to women, Swedes are the least likely, and Americans are situated between the two. Attitudinal data on the division of labor by gender show that, in 1982, almost two thirds of the Japanese women surveyed $(60 \%)$, about a quarter of the American women (26\%), and only $13 \%$ of the Swedish 
women agreed with the statement, "Women are supposed to work in the home and men are supposed to work in the labor market" (Inoue \& Ehara, 1995). By 1997, the percentage of Japanese women who agreed with this statement decreased to approximately $40 \%$ (those for Swedish and American women are not available), a percentage still substantially higher than that of the American and Swedish samples in 1982 (Gender Equality Bureau, 1998). Data on attitudes toward politicians show that among equivalent samples from six industrialized countries that are similarly affluent (i.e., Finland, Japan, Norway, Sweden, West Germany, and the United States), Japanese are the most likely to preferentially assign political work to men over women, and Swedes and Norwegians are the least likely to show such preferences (Norris \& Inglehart, 2000). Norris and Inglehart also showed that the preferential assignment of political work to men among the Japanese is stronger than that among respondents of many developing countries, including India, Chile, and Taiwan. Behavioral data on time use from the mid-1990s (Juster, Ono, \& Stafford, 1999) indicate that Swedish women allocate only $15 \%$ more of their work time to housework (as opposed to labor market work) than do Swedish men, U.S. women allocate $30 \%$ more of their work time to housework than do U.S. men, and Japanese women allocate $47 \%$ more of their work time to housework than do men.

Other statistics suggest that, in countries with a higher degree of role differentiation by gender, women receive smaller economic returns from their human capital investment than do men, which may be a source of stress and inefficiency for working women. Gendered gap in earnings, which is often cited as an index of gendered discrimination at work (Treiman \& Hartmann, 1981), is the largest in Japan, smaller in the United States than in Japan, and the smallest in Sweden. Blau and Kahn (2000) find that, from 1994 to 1998 among full-time workers, women's average earnings as a proportion of men's was $64 \%$ in Japan, $76 \%$ in the United States, and $84 \%$ in Sweden. In contrast, no gendered gap in human capital accumulation for entry-level work, as measured by the expected years of education, is found in any of the three countries, including Japan (World Bank, 2001). Employment discrimination on the basis of gender is illegal in all three countries (Meyersson-Milgrom, Petersen, \& Snartland, 2001; Thode, Esche, \& Gramke, 2001). Thus, laws and policies may not necessarily reflect the extent of exclusion experienced by women in these countries. The magnitude of the gendered gap observed across countries, however, is correlated with the percentage of women in positions of institutional influence. As of June 2000, the percentage of female parliamentarians (i.e., those elected into the lower house of the national parliament) was $43 \%$ in Sweden, $13 \%$ in the United States, and only $5 \%$ in Japan (Norris \& Inglehart, 2000).

These statistics on gender, combined with the consistent findings among previous studies that a higher level of women's income increases the chance of marriage at a given time in the contemporary United States (Lichter et al., 1992; Sweeney, 2002), suggest a specific contextual variation hypothesis: Women's higher economic standing, as measured by income, should increase the chance of first marriage in the United States and in Sweden (i.e., the more egalitarian contexts on the basis of gender than the United States) but should reduce the chance in Japan (i.e., the more differentiated context on the basis of gender than the United States). The same hypothesis is derived from defining a relatively egalitarian context as one in which the majority of wives are employed: Less than half $(45 \%)$ of Japanese wives were working in 1995 (Gender Equity Bureau, 1998), but the majority of American (61\%) and Swedish (82\%) wives were working in the late 1990s (Statistics Sweden, 2002; U.S. Bureau of Census, 2001).

Virtually no difference in aggregate economic positions, as measured by Gross National Income (GNI, formerly known as Gross National Product), are found among the three countries, particularly on the logarithmic scale (Norris \& Inglehart, 2000). The countries differ somewhat in income range (Smeeding, 2001); however, no available theories lead to the expectation that income range is linked to cross-national variation in the relationship between women's income and first marriage timing. Because previous research on the U.S. and Sweden reports that marriage timing and women's income are correlated with education (e.g., Sweeney, 2002), economic position of men in the local area (e.g., Lewis \& Oppenheimer, 2000), sex ratio (e.g., South \& Trent, 1988), cohabitation (Bracher \& Santow, 1998), school enrollment status (e.g., Oppenheimer \& Lew, 1995), and premarital fertility (e.g., Duvander, 1999), these conditions are controlled in the analysis. 


\section{METHOD}

To test the universality hypothesis against the contextual variation hypothesis, public use panel data sets from Japan (JPSC), the United States (PSID), and Sweden (SHMNA) are analyzed. These panel surveys follow individuals over time, recording changes in their economic status and family structure. The sample for analysis from each country is restricted to never-married women because the formation of second and higher order marriages may involve different social processes from that of the first marriage (Sweet \& Bumpass, 1987). Women in the sample are not excluded on the basis of their employment status. Each of the three panels is described briefly in more detail in the next three paragraphs.

The JPSC is an annual panel survey conducted by the Institute for Research on Household Economics. Five waves of data, collected annually between 1993 and 1997, are available for public use. The national representative sample of a cohort of young women aged 25 to 34 contains approximately 1,000 married and 500 unmarried women (almost all of whom were never married) at the baseline year of 1993. Each year, the women were asked about themselves, their husbands and children, and other relatives present in the household.

The PSID, a longitudinal panel survey with a national representative sample of individuals and households in the United States, is conducted by the Survey Research Center of the University of Michigan. It followed individuals and families annually between 1968 and 1997. Respondents are generally heads of the household who answer questions about family members. Begun with 5,500 households, the sample has increased as the children of baseline families established their own households ("split-off" families). To standardize the U.S. analytic sample to the Japanese and Swedish samples, which contain solely majority race respondents, only data for non-Hispanic Whites are included in the analysis. Although the panel has a large sample of individuals (approximately 26,000 in 1990), which includes children, the elderly, and married adults, it has a relatively small sample of interest for this study. About 3,650 White women between the ages of 18 and 55 are in the panel in 1990, but the number declines substantially when further restricting the sample to never-married women.

The SHMNA is a Swedish panel data set collected in the Department of Economics at Uppsala University. It began in 1984 with a national rep- resentative sample of more than 2,300 households, consisting of household heads age 18 to 74 . The household members were interviewed again in 1986, 1988, 1991, 1993, and 1996. The structure of the sample is generally similar to that of the PSID. The Swedish data set has some limitations for the purpose of this study, such as infrequently ascertained marital status in the 1980s and the low quality of retrospective marital history information. Also, because of the anomalous rise in marriage rates in 1989 with the widow's pension reform (Hoem, 1991), the analysis excludes data from the 1991 wave, which contain information on marriages formed between 1988 and 1991. Thus, only two waves of Swedish panel data, 1993 and 1996, are used in the analysis, with the information from the retrospective marital history component excluded. Even with these limitations, the Swedish Household Market and Nonmarket Activity is the only longitudinal data set publicly available in Sweden.

The Japanese cohort data are relatively restricted in age range. In contrast, an open age range is available for the American and Swedish samples, which provides flexibility in defining the American and Swedish cohorts used for analysis. By cohorts, I refer to samples restricted in age range at the first year of observation, and which are followed up without replacement. I used three alternative age ranges to define the American and Swedish cohorts, all of which yielded the same results regarding the effect of women's income on the chance of first marriage. First, I used the maximum age range available in each of the two data sets at the first year of observation: 18-53 and 1857 for the American and Swedish samples, respectively. Second, I used the same age range as available in the Japanese sample: 25-34 in the first year of observation. Third, I used the 10th to the 99th percentile age range in which first marriages are formed in the United States and Sweden. This approach modifies the second approach by adjusting for the fact that first marriages form in a larger age range in the United States and Sweden than in Japan. Data from the 1995 Japanese Census (Ministry of Public Management, 1995) indicate that the age range over the observational periods of the Japanese sample (25-39) excludes the ages in which the earliest $9 \%$ and the latest $1 \%$ of first marriages occur in the country. Using information on data published by the United States and Swedish governments (Statistics Sweden, 2002; U.S. Department of Health \& Human Services, 1995), the age ranges of the American 
and Swedish samples were chosen in ways that eliminated the ages in which the earliest $9 \%$ and the latest $1 \%$ of the first marriages form in the two countries. The resulting age range was 19-36 in the first year of observation (26-43 in the last year) for the American sample and 26-52 in the first year (29-55 in the last year) for the Swedish sample. The results presented here are from the use of the last approach to restricting the American and Swedish age range.

For the Japanese and the American samples, the observational period is 1 calendar year, with four and seven observational periods, respectively. A sample member is dropped once she marries. The risks are calculated for each individual at a given age under the assumption of proportionality (i.e., no interaction effect between a covariate and time) typical to hazard models. The Swedish sample has one observational period, which spans 3 years, partly because of the limitation in the retrospective data. As a result, the covariates for the Swedish data are measured at 3 years prior to year $t$ rather than 1 year prior to year $t$. Assessments from the Japanese and American samples showed that the use of one 3-year interval instead of three 1-year intervals to observe first marriages increased the magnitude of the coefficients and the standard errors proportionally. It did not alter the sign and the statistical significance of the coefficients, however, which are the indicators of interest in this study.

\section{Dependent Variable}

Log-odds of a first marriage in time interval $t$ is the dependent variable. It is coded 1 if married in time interval $t$, and 0 otherwise. First union, which combines first cohabitation and first marriage, was not a useful alternative dependent variable for the American and Swedish samples because marriage and cohabitation are not equivalent unions in the two countries, and the Swedish and American panel data sets have incomplete information on cohabitation history and no information on the order of the observed cohabitation.

\section{Covariates}

The covariate of interest in this study is women's actual total income (1995 U.S. dollars) at time $t-1$ (year) or $t-3$ (years). It is adjusted across years and countries with the consumer price index and purchasing power parity. Total income (zero income included) consists of a variety of components, such as labor income, income from assets, and transfer income, and is included in the regressions in a logarithmic form. In the Japanese sample, some women (approximately 10 persons per year) quit their jobs in anticipation of a marriage. To correct for this endogeneity problem, I use these women's income in year $t-2$ (2 years prior, adjusted for inflation) as estimates of their income in year $t-1$ (the previous year) had they not quit their job in anticipation of a marriage.

Measures of women's future economic prospects and the quantity and quality of men in the local area are included as control variables. The variable years of education at time $t-1$ or $t-$ 3 or the total number of years of schooling attained at the time of the interview measures women's future economic prospects with a common metric in all three countries (Treiman, 1977). To control for the quantity and quality of the men in the local marriage market (i.e., women's potential mates), two variables are used: sex ratio in the local area of the persons within the respondent's 5-year age group and mean annual labor income of men in the local area in the same age group at year $t-1$ or $t-3$ (1995 U.S. dollars). Local areas are defined by prefecture in Japan, metropolitan area (MSA/PMSA) combined with Public Use Microdata Sample Areas (PUMA) in the United States, and municipality in Sweden. Sex ratios and men's earnings in the local area for the United States are obtained from the 1990 Census 5\% Public Use Microdata Samples (PUMS) file. Labor income of American men is calculated for White men only, the racial group from which White women are most likely to select mates (Qian, 1997). The two measures for Sweden are constructed from tables of local area sex ratio and mean earnings for 1995 provided by Statistics Sweden. The two measures for Japan are from the 1995 Census (Ministry of Public Management, Home Affairs, \& Posts \& Telecommunications, 2000) and survey results published by the Ministry of Labor for 1995 (1996). Earnings combine salary and bonus, which is a large part of labor income in Japan.

In part of the analysis of the Swedish and American samples, three additional control variables are included: cohabitation, school enrollment status, and premarital fertility. These variables are not included in the analysis of the Japanese sample because of sparse observations. Live in a cohabiting union in year $t-1$ or $t-$ 3 is coded 1 if true, and 0 otherwise. In Sweden, 
approximately $80 \%$ of the married couples first entered cohabitation before marriage (Moen, 1989), and, in the more recent years in the United States, about $50 \%$ of the married couples cohabited before marriage (Bumpass \& Lu, 2000). Cohabitation among the Japanese is rare and is estimated at $1 \%$ among the never-married population (Ministry of Health, Labor \& Welfare, 1998), in light of the fact that almost all (96\%) of the never-married Japanese eventually marry (Ministry of Public Management, 1995), the statistics imply that a very small percentage of Japanese marriages are preceded by cohabitation. Enrollment status in year $t-1$ or $t-3$ is included to account for the potential that enrolled students may delay marriage until they have obtained their degree (Blossfeld, 1995; Oppenheimer \& Lew, 1995). According to the statistics provided by the National Center for Educational Statistics (2001), substantial percentages of 26- to 29-year-old men and women in the United States were in school in the mid-to-late 1990s (11\%) and Sweden (12.5\%). In contrast, a much smaller percentage $(2.5 \%)$ of their Japanese counterparts were in school during these years. Number of children in year $t-1$ or $t-3$ is included as a linear term. Comparative statistics published by the U.S. Bureau of Census (1994) indicate that nonmarital births accounted for about 50\% of all 1992 births in Sweden, about $30 \%$ in the United States, and only about $1 \%$ in Japan.

Age at time $t-1$ or $t-3$ is included as a time counter. Although measures of parental socioeconomic status, such as father's and mother's educational attainment, were included in the original analysis, they were found nonsignificant and are excluded from the results presented here. Exploratory analysis of the Japanese sample also included a variable to control for coresidence with parents. The inclusion of this variable did not alter the Japanese results in a major way. I present a version of the Japanese results from an equation that excluded parental coresidence.

\section{Analytical Strategy}

Discrete-time event-history regressions are used to estimate the sign and the statistical significance of the coefficient of women's income in the three countries. For the Swedish case, where there is only one observational period, the regressions become binary logistic regressions. The equations are applied to data from each country separately.

A common response to discrete-time event-his- tory models is that multiple observations per person and different number of observations per person may cause observational dependence that biases the standard errors and the test statistics (Allison, 1995). Allison notes and empirically demonstrates that these concerns are not applicable to event-history models when the event analyzed occurs only once in an individual's life, such as first marriage. In these models, multiple observations are used to calculate the likelihood function, allowing a researcher to estimate the conditional probability of an event occurring at time $t$, given that the event has not occurred prior to time $t$.

One equation is applied to the Japanese sample and two equations are applied to the American and Swedish samples. The first equation includes all covariates except for school enrollment, number of children, and cohabitation. The coefficient estimate of women's income in this equation yields the effect of women's current economic standing on the chance of first marriage in a period, net of the effects of women's future economic prospect, as measured by women's education, and the quantity and quality of men in the local area, as measured by sex ratio and average earnings of men. The second equation adds the three covariates (i.e., enrollment, children, and cohabitation) to the first equation and is applied only to the American and Swedish samples. This equation serves as a sensitivity test to processes that are nearly absent among never-married women in the age range in Japan. The coefficients obtained from the first and second equations are converted to odds multipliers, which aid interpretation by indicating the multiplicative change in the odds with a unit increase in a covariate. They are the exponent of the coefficient estimates.

Table 1 shows the means and standard deviations of the covariates for the person-periods. The mean annual incomes are reported in the prelogarithmic form. In the Japanese cohort sample, of the 456 never-married women, 159 married over the subsequent 4 years (1994-1997). In the American cohort sample, of the 410 never-married American women aged 19-36 in 1990, 179 married over the 7 years of observation (1991-1997). In the Swedish cohort sample, of the 455 nevermarried Swedish women aged 26-52 in 1993, 96 married by the 1996 panel. Because more and shorter person-periods are available from the Japanese and American data, they indicate lower marriage rates (.13 and .09 , respectively) than do the Swedish person-periods (.21). When proportions of Japanese and American women who mar- 
Table 1. Unweighted Means and Standard Deviations of the Person-Period Samples, United States, Japan, AND SWEDEN

\begin{tabular}{|c|c|c|c|c|c|c|}
\hline \multirow[b]{2}{*}{ Variables } & \multicolumn{2}{|c|}{ Japan } & \multicolumn{2}{|c|}{ U.S. } & \multicolumn{2}{|c|}{ Sweden $^{\mathrm{a}}$} \\
\hline & $M$ & $S D$ & $M$ & $S D$ & $M$ & $S D$ \\
\hline Marriage in a period & .13 & .33 & .09 & .26 & .21 & .41 \\
\hline \multicolumn{7}{|l|}{ Women's economic standing } \\
\hline Total income $(\times 1,000)$ & 17.32 & 7.28 & 16.29 & 27.24 & 10.47 & 3.89 \\
\hline \multicolumn{7}{|l|}{ Controls } \\
\hline \multicolumn{7}{|l|}{ Future economic prospects } \\
\hline Education & 13.74 & 1.53 & 12.84 & 1.95 & 11.61 & 1.43 \\
\hline \multicolumn{7}{|l|}{ Quantity and quality of men in the local area } \\
\hline Sex ratio in the local area & 1.03 & .09 & 1.01 & .08 & 1.01 & .05 \\
\hline Employed men's earnings in the local area $(\times 1,000)$ & 26.75 & 4.26 & 23.83 & 10.53 & 15.94 & 4.09 \\
\hline Cohabitation & - & - & .06 & .19 & .13 & .34 \\
\hline Enrollment & - & - & .10 & .31 & .06 & .24 \\
\hline Number of children & - & - & .38 & .74 & .45 & .48 \\
\hline \multicolumn{7}{|l|}{ Time } \\
\hline Age & 29.03 & 2.84 & 31.53 & 5.13 & 35.33 & 2.71 \\
\hline$n$ (person-periods) & 1,131 & & 2,326 & & 455 & \\
\hline
\end{tabular}

Note: Data are from the Japanese Panel Survey on Consumers, Panel Study of Income Dynamics, and Swedish Household Market and Nonmarket Activity.

${ }^{a}$ A woman in the Swedish sample has data for only one period of observation. In contrast, a woman in the Japanese and American samples has data for multiple periods of observation.

ry over the years are calculated, they are considerably higher (.35 and .44 , respectively) than the Swedish proportion of .21.

The average income level of the Japanese sample may appear too high to individuals unfamiliar with contemporary Japan. The average annual income of these never-married Japanese women is actually lower, however, than the average annual earnings of Japanese women who are employed full time year around, as reported by the Ministry of Labor (1996). This is partly because some of the sample members do not work (at one time) during the year. According to the Ministry (p. 76), the average salary plus bonus of a 25- to 29-yearold Japanese woman with 5-9 years of work experience who is employed full time all year is 323,600 yen per month, or approximately $\$ 1,938$ per month (1995 U.S. dollars, Consumer Price Index-Purchasing Power Parity adjusted) and $\$ 23,256$ annually (Ministry of Labor, p. 76).

\section{RESULTS}

Table 2 displays results from the two sets of regressions, those excluding school enrollment, cohabitation, and number of children for the three countries (columns 1,2, and 4), and those including the three control variables for the American and Swedish samples (columns 3 and 5). It also displays the corresponding odds multipliers. The estimates presented here are from samples of women in the 10th to the 99th percentile of age ranges in which (early to late) first marriages form in the three countries. The first set of results in columns 1, 2, and 4 measures the effect of women's income on the chance of first marriage, net of the effect of women's education, local area sex ratio, and men's average earnings in the local area. The sign of the coefficient of women's income is negative in the Japanese sample (Column 1) and positive in the American (Column 2) and the Swedish samples (Column 4), which is consistent with the contextual variation hypothesis and contrary to the universality hypothesis. More specifically, although Japanese women with a higher level of income in the previous period are less likely to marry in the current period than are women with a lower level of income, American and Swedish women with a higher level of income are more likely to marry in the period. Odds multipliers indicate that, net of the effects of education, local area sex ratio, and men's average earnings in the local area, Japanese women's chance of first marriage in a year declines approximately $3 \%$ with each successive increase in income. In contrast, the same increase in women's income raises the chance of first marriage in a year by 
Table 2. Regressions Predicting the Log-odds of First Marriage Among Never-Married Women in Japan, THE UNITED STATES, AND SwEDEN

\begin{tabular}{|c|c|c|c|c|c|c|}
\hline \multirow[b]{3}{*}{ Covariate } & \multirow{2}{*}{\multicolumn{2}{|c|}{$\begin{array}{c}\text { Japan } \\
(1) \\
\end{array}$}} & \multicolumn{4}{|c|}{ U.S. } \\
\hline & & & \multicolumn{2}{|l|}{ (2) } & \multicolumn{2}{|l|}{ (3) } \\
\hline & $\beta$ & $\operatorname{Exp}(\beta)$ & $\beta$ & $\operatorname{Exp}(\beta)$ & $\beta$ & $\operatorname{Exp}(\beta)$ \\
\hline \multicolumn{7}{|l|}{ Women's economic standing } \\
\hline Total income $(\times 1,000)$ & $\begin{array}{c}-.033^{*} \\
(.014)\end{array}$ & .967 & $\begin{array}{l}.021 * * * \\
(.002)\end{array}$ & 1.021 & $\begin{array}{l}.016 * * * \\
(.002)\end{array}$ & 1.016 \\
\hline \multicolumn{7}{|l|}{ Controls } \\
\hline \multicolumn{7}{|l|}{ Future economic prospects } \\
\hline Educational attainment & $\begin{array}{l}.003 \\
(.055)\end{array}$ & 1.003 & $\begin{array}{l}.107 * \\
(.061)\end{array}$ & 1.113 & $\begin{array}{l}.301 * * * \\
(.064)\end{array}$ & 1.351 \\
\hline \multicolumn{7}{|c|}{ Quantity and quality of men in the local area } \\
\hline Sex ratio in the local area & $\begin{array}{l}2.769 * * \\
(.981)\end{array}$ & 15.942 & $\begin{array}{c}.802 \\
(1.019)\end{array}$ & 2.229 & $\begin{array}{c}1.994 \\
(1.104)\end{array}$ & 7.345 \\
\hline $\begin{array}{l}\text { Employed men's earnings in the } \\
\text { local area }(\times 1,000)\end{array}$ & $\begin{array}{l}.049 * \\
(.023)\end{array}$ & 1.050 & $.025^{*}$ & 1.025 & $\begin{array}{l}.022 \\
(.013)\end{array}$ & 1.022 \\
\hline Cohabitation & - & - & - & - & $\begin{array}{l}1.761 * * \\
(.556)\end{array}$ & 5.818 \\
\hline Enrollment & - & - & - & - & $\begin{array}{c}-.700 * \\
(.334)\end{array}$ & 0.497 \\
\hline Number of children & - & - & - & - & $\begin{array}{l}.531 * * * \\
(.097)\end{array}$ & 1.701 \\
\hline \multicolumn{7}{|l|}{ Time } \\
\hline Age & $\begin{array}{c}-.097 * \\
(.041)\end{array}$ & .907 & $\begin{array}{l}-.082 * * * \\
(.022)\end{array}$ & 0.921 & $\begin{array}{l}-.152 * * * \\
(.032)\end{array}$ & 0.859 \\
\hline Constant & $\begin{array}{c}-2.854 \\
(1.581)\end{array}$ & & $\begin{array}{c}-3.551 * \\
(1.304)\end{array}$ & & $\begin{array}{l}-8.320 * * * \\
(1.920)\end{array}$ & \\
\hline $\begin{array}{l}\text { Log likelihood } \\
n\end{array}$ & $\begin{array}{l}-472 \\
1,131\end{array}$ & 996 & -467 & & -410 & \\
\hline
\end{tabular}

Note: Standard errors are in parentheses. Data are from the Japanese Panel Survey on Consumers, Panel Study of Income Dynamics, and Swedish Household Market and Nonmarket Activity.

$* p<.05 . * * p<.01 . * * * p<.001$ (two-tailed tests).

$2.1 \%$ for the American women and by $6.4 \%$ over the 3-year period for Swedish women.

Is the conclusion drawn from the coefficients of women's income in the first equation (columns 1,3 , and 5) altered when controlling for school enrollment, cohabitation, and premarital births (i.e., the influences of processes that receive relatively little weight in the Japanese case)? The second set of estimates suggests this is not the case. The coefficient estimates of women's income for the Swedish and the U.S. samples in the second set of regressions (columns 3 and 5), together with those in the first (columns 2 and 4), indicate that they are weakened but not changed in sign or statistical significance after controlling for the three influences. Additional path analysis indicated that the indirect effect of women's income on the chance of first marriage through cohabitation in Sweden and the United States accounted for the weakening effect of women's income relative to that estimated in the first equation (not shown). That is, the results suggest that in these two countries, a higher level of women's income increases the chance of cohabitation, which in turn raises the chance of first marriage. Thus, this indirect effect composes part of the effect of women's income estimated in the first equation for the Swedish and U.S. samples. The odds multipliers indicate that, once removing the indirect effect of women's income through cohabitation, a $\$ 1,000$ increase in women's income now raises the risk of marriage by $1.6 \%$ in 1 year among the single American women and by 5.3\% in 3 years among the single Swedish women.

\section{DISCUSSION}

This study tests the universality hypothesis against the contextual variation hypothesis by investigating whether women's economic contribution, as 
TABLE 2. EXTENDED

\begin{tabular}{|c|c|c|c|}
\hline \multicolumn{4}{|c|}{ Sweden } \\
\hline \multicolumn{2}{|l|}{ (4) } & \multicolumn{2}{|l|}{ (5) } \\
\hline$\beta$ & $\operatorname{Exp}(\beta)$ & $\beta$ & $\operatorname{Exp}(\beta)$ \\
\hline $\begin{array}{c}0.62 * \\
(.023)\end{array}$ & 1.064 & $\begin{array}{l}.052 * \\
(.025)\end{array}$ & 1.053 \\
\hline $\begin{array}{l}.034 \\
(.053)\end{array}$ & 1.034 & $\begin{array}{l}.047 \\
(.053)\end{array}$ & 1.048 \\
\hline $\begin{array}{c}2.832 * \\
(1.251)\end{array}$ & 16.979 & $\begin{array}{c}1.251 \\
(1.599)\end{array}$ & 3.494 \\
\hline $\begin{array}{l}.046^{*} \\
(.019)\end{array}$ & 1.047 & $\begin{array}{l}.030 \\
(.024)\end{array}$ & 1.030 \\
\hline - & - & $\begin{array}{l}2.209 * * * \\
(.349)\end{array}$ & 9.107 \\
\hline - & - & $\begin{array}{c}-.405 \\
(.438)\end{array}$ & .667 \\
\hline - & - & $\begin{array}{c}.159^{*} \\
(.077)\end{array}$ & 1.172 \\
\hline $\begin{array}{c}-.084 * * * \\
(.027) \\
-1.773 \\
(1.764)\end{array}$ & 0.919 & $\begin{array}{c}-.072 * * * \\
(.019) \\
-2.627 \\
(1.957)\end{array}$ & 0.931 \\
\hline-200 & & -17 & \\
\hline
\end{tabular}

measured by their income, prevents first marriage formation in all national contexts or only in national contexts that are relatively differentiated by gender. It is the first systematic test of the competing cross-national hypotheses with data from Japan, the United States, and Sweden. In the case of Japan, it is the first report of results on the effect of never-married women's income on their first marriage timing using longitudinal data.

The results support the contextual variation hypothesis and counter the universality hypothesis implied by the theory of specialization and exchange. In particular, for samples of each country, when controlling for the level of education, local area sex ratio, and earnings of men in the local area, a higher level of women's income decreases the chance of first marriage in a period among Japanese women but increases the chance of first marriage among both American and Swedish women. The sign reversal in the effect of women's income across contexts of gender has not been captured in intracountry studies that use historical contexts to proxy shifts in the degree of role dif- ferentiation by gender (e.g., Santow \& Bracher, 1994; Sweeney, 2002). The results are consistent with the view that when women make economic contributions in industrialized countries with a relatively high degree of role differentiation, they experience stresses and inefficiencies in their lives in ways that conflict with the formation of marriage. In countries with a relatively low degree of role differentiation by gender, however, women of high economic status are more attractive in the marriage market as a result of the symmetry in the criteria of mate selection between the sexes (Duvander, 1999; Sweeney, 2002).

The analyses were limited by data availability. For example, the age range in which the earliest $9 \%$ of first marriages take place is eliminated from the analysis as a result of the age restrictions on the Japanese sample. In the Swedish and the American samples, additional analyses indicated that the basic results do not change with the inclusion of women younger than age 25 . I did not have data on Japanese women younger than age 25 , however. It is possible that an analysis of microlevel longitudinal data with never-married Japanese women younger than age 25 would lead to an alternative conclusion, but Raymo's (1998) aggregate level findings suggest otherwise. In addition, I was not able to estimate empirically the influences of school enrollment, cohabitation, and premarital fertility on the chance of first marriage in Japan. To estimate these influences in Japan, I would need a longitudinal data set with a very large sample of never-married Japanese women. Such data are currently unavailable. Finally, I analyzed data from only three affluent industrialized countries. Whether the inclusion of additional affluent industrialized countries with similar aggregate economic positions would alter the conclusion needs to be examined in future studies.

Despite these constraints, the results provide insights into whether postindustrial societies are at growing risk for the demise of marriage (e.g., Bumpass, 1998). They imply that marriage is suppressed by women's expanding economic contribution only in those industrialized countries with a relatively high degree of role differentiation by gender, such as Japan. Whether an industrialized country uses female labor to meet its requirements and transforms its norms in ways that promote a compatibility between women's economic contribution and marriage formation may be mediated by the country's background. One can argue that only an atypical industrialized country would experience severe lags in the adoption of norms and 
practices that tend to support women's economic contribution as a result of its sociocultural and economic background. Industrialized countries more commonly depend on the labor-force participation of both men and women to sustain their economic growth (Oppenheimer, 1970) and more easily accept and adopt supportive norms and practices. The results also imply that industrialization is not a sufficient condition to produce uniformity in the effect of women's economic standing on marriage formation.

The findings have policy implications. For example, as Japanese women gain equality by gender, they could reverse the marriage-depressive effect of their economic resources on first marriage timing. This is encouraging news for Japanese political leaders, who have expressed major concerns over the declining marriage rates, which is potentially induced by the increasing economic participation of women (Ministry of Health, Labor, \& Welfare, 1998). They recognize that low marriage rates lead to low fertility rates and the instability of the social security system (Atoh, 1994). The Japanese situation demonstrates that when an industrialized country does not experience institutional and cultural change with the increasing demand for female labor, it could encounter unanticipated long-term consequences.

The results indicate that in the United States and Sweden, a higher level of women's income indirectly raises the chance of marriage by encouraging cohabitation. They are consistent with previous findings (e.g., Bracher \& Santow, 1998; Clarkberg, 1999; Duvander, 1999) and with the view that cohabitation is a period in which (dualcareer) couples negotiate the division of labor to make marriage formation viable (Cherlin, 2000; Manning \& Smock, 1995; Seltzer, 2000). They imply that as women make greater economic contributions, the need for couples to negotiate the division of labor during cohabitation before marriage increases.

Investigation of whether aggregate economic conditions differentiate the effect of women's income (on the chance of first marriage) across countries is out of the scope of this study. By focusing on the three industrialized countries with similar aggregate economic standing, this study holds constant that dimension of potential influence. If the influence of aggregate economic conditions were to be studied, another set of countries should be selected that vary substantially on the dimension of aggregate economic conditions but have a similar level of role differentiation by gen- der. Such an investigation may be pursued in a separate study.

An even more ambitious extension of this study would place the analysis in a formal multilevel framework. In this framework, the countrylevel effects (e.g., gendered expectation of the population and per capita GNI) would be interacted with individual-level effects, such as women's income. These interaction terms would allow a researcher to test, for example, whether the magnitude of the effect of women's income differs significantly with variation in a country-level variable. Empirical estimation of a multilevel model would require the inclusion of a substantial number of additional countries. Entwisle and Mason (1985) report that estimating two macrolevel effects requires at least 15 countries. A formal multilevel study would also require data (e.g., the length of the observed period) that are even more standardized than those available in this study, so that the magnitude of the effect of women's income could be compared across countries. The current study serves as a first step toward such a long-term effort.

\section{Note}

An earlier version of this paper was presented at the Population Association of America, 2001, Washington, DC. The research was supported by funds from the United States-Japan Foundation, the Alfred Sloan Foundation (University of Michigan Center for the Ethnography of Everyday Life), and the Abe Fellowship administered by the Social Science Research Council. I thank Sanjiv Gupta, Jim Raymo, Erik Liljetren, Lennart Flood, Anders Klevmarken, Akiko Nagai, Charles Horioka, N. E. Barr, Pamela Smock, and So-Young Lim for their helpful input.

\section{REFERENCES}

Allison, P. D. (1995). Survival analysis using the SAS system: A practical guide. Cary, NC: SAS Institute.

Atoh, M. (1994). The recent rise in proportion single and the postponement of marriage in Japan. Japanese Journal of Family Sociology, 6, 5-18.

Becker, G. S. (1981). A treatise on the family. Cambridge, MA: Harvard University Press.

Blau, F. D., \& Kahn, L. M. (2000). Gender difference in pay. Russell Sage Foundation Working Paper Series. New York: Russell Sage Foundation.

Blossfeld, H. P. (1995). Introduction. In H. P. Blossfeld (Ed.), The new role of women: Family formation in modern societies (pp. 3-13). Boulder, CO: Westview Press.

Bracher, M., \& Santow, G. (1998). Economic independence and union formation in Sweden. Population Studies, 52, 275-294.

Bumpass, L. (1998). Declining significance of marriage in the U.S. In K. O. Mason, N. O. Tsuya, \& M. K. 
Choe (Eds.), The changing family in comparative perspective: Asia and the United States (pp. 43-62). Honolulu: East-West Center, Published in cooperation with University Research Center, Nihon University, Tokyo.

Bumpass, L., \& Lu, H. H. (2000). Trends in cohabitation and implications for children's family contexts in the United States. Population Studies, 54, 29-41.

Cherlin, A. (2000). Toward a new home socioeconomics of union formation. In L. J. Waite, C. Bachrach, M. Hindin, E. Thomson, \& A. Thornton (Eds.), The ties that bind: Perspectives on marriage and cohabitation (pp. 126-144). New York: Aldine de Gruyter.

Clarkberg, M. (1999). The price of partnering: The role of economic well-being in young adults' first union. Social Forces, 77, 945-968.

Conger, R. D., Elder, G. H., Lorenz, F. O., Conger, K. J., Simons, R. L., Whitbeck, L. B., Huck, S., \& Melby, J. N. (1990). Linking economic hardship to marital quality and instability. Journal of Marriage and Family, 52, 643-656.

Duvander, A. Z. (1999). The transition from cohabitation to marriage: A longitudinal study of the propensity to marry in Sweden in the early 1990s. Journal of Family Issues, 20, 698-717.

Entwisle, B., \& Mason, W. M. (1985). Multilevel effects of socioeconomic development and family planning programs on children ever born. American Journal of Sociology, 91, 616-649.

Gender Equity Bureau, Cabinet Office of Japan. (1998). Annual report. Tokyo: Cabinet Office.

Hochschild, A. R. (1989). The second shift: Working parents and the revolution at home. New York: Viking.

Hoem, J. M. (1991). To marry, just in case ... : The Swedish widows'-pension reform and the peak in marriages in December 1989. Acta Sociologica, 34, $127-135$.

Inoue, T., \& Ehara, Y. (1995). Women's data book. Tokyo: Meisensha.

Juster, T., Ono, H., \& Stafford, F. (1999, March). Time use. Paper presented at the annual meetings of the Sloan Centers for Work and Family, San Francisco.

Leslie, J., \& McGee, M. (2000). Invented identities: The interplay of gender, religion, and politics in India. New Delhi: Oxford University Press.

Lewis, S. K., \& Oppenheimer, V. K. (2000). Educational assortative mating across marriage markets: Non-Hispanic Whites in the United States. Demography, 37, 29-40.

Lichter, D. T., McLaughlin, D. K., Kephart, G., \& Landry, D. J. (1992). Race and the retreat from marriage: A shortage of marriagable men? American Sociological Review, 57, 781-799.

Manning, W., \& Smock, P. J. (1995). Why marry? Race and the transition to marriage among cohabitors. Demography, 32, 509-520.

Meyersson-Milgraom, E. M., Petersen, T., \& Snartland, V. (2001). Equal pay for equal work? Evidence from Sweden and a comparison with Norway and the U.S. Scandinavian Journal of Economics, 103, 559-583.

Ministry of Health, Labor \& Welfare. (1998). Annual report: On the low fertility nation. Tokyo: Author.

Ministry of Labor. (1996). Basic survey on wage structure, Vol. 1. Tokyo: Author.
Ministry of Public Management. (1995). Population census of Japan. Tokyo: Author.

Ministry of Public Management, Home Affairs \& Posts and Telecommunications. (2000). Final report of the 1995 population census. Tokyo: Nihon Tokei Kyokai.

Moen, P. (1989). Working parents: Transformations in gender roles and public policies in Sweden. Madison: University of Wisconsin Press.

Mosesdottir, L. (2000). Pathways towards the dual breadwinner model: The role of the Swedish, German and the American States. International Review of Sociology, 10, 189-205.

National Center for Educational Statistics. (2001). Digest of educational statistics. Washington, DC: Government Printing Office.

Norris, P., \& Inglehart, R. (2000). Cultural barriers to women's leadership: A worldwide comparison. Paper presented at the International Political Science Association World Congress, Quebec City.

Oppenheimer, V. K. (1970). The female labor force in the United States. Westport, CT: Greenwood Press.

Oppenheimer, V. K. (1988). A theory of marriage timing: Assortative mating under varying degrees of uncertainty. American Journal of Sociology, 94, 563591.

Oppenheimer, V. K. (1997). Women's employment and the gain to marriage: The specialization and trading model. Annual Review of Sociology, 23, 431-453.

Oppenheimer, V. K., \& Lew, V. (1995). American marriage formation in the 1980s: How important was women's economic independence? In K. O. Mason \& A. M. Jensen (Eds.), Gender and family change in industrialized countries (pp. 105-138). Oxford: Clarendon Press.

Pinelli, A., \& De Rose, A. (1995). Italy. In H. P. Blossfeld (Ed.), The new role of women: Family formation in modern societies (pp. 174-190). Boulder, CO: Westview Press.

Qian, Z. (1997). Breaking the racial barriers: Variations in interracial marriage between 1980 and 1990. Demography, 34, 263-276.

Raymo, J. M. (1998). Later marriages or fewer? Changes in the marital behavior of Japanese women. Journal of Marriage and Family, 60, 1023-1034.

Santow, G., \& Bracher, M. (1994). Change and continuity in the formation of first marital unions in Australia. Population Studies, 48, 475-496.

Seltzer, J. A. (2000). Families formed outside of marriage. Journal of Marriage and Family, 62, 12471268.

Smeeding, T. M. (2001). The gap between rich and poor: A cross-national perspective for why inequality matters and what policy can do to alleviate it. Paper presented at the National Institute of Population and Social Security Research, Tokyo, Japan.

South, S. J. (2001). Time dependent effect of wives' employment on marital dissolution. American Sociological Review, 66, 226-245.

South, S. J., \& Trent, K. (1988). Sex ratios and women's roles: A cross-national analysis. American Journal of Sociology, 93, 1096-1115.

Statistics Sweden. (2002). Statistical yearbook of Sweden, 2002. Stockholm: Author.

Sweeney, M. (2002). Two decades of family change: The shifting economic foundations of marriage. American Sociological Review, 67, 132-147. 
Sweet, J. A., \& Bumpass, L. L. (1987). American families and households. New York: Russell Sage Foundation.

Thode, E., Esche, A., \& Gramke, K. (2001). International reform monitor. Social policy, labor market policy and industrial relations. Gutersloh: Bertelsmann Foundation.

Treiman, D. J. (1977). Occupational prestige in comparative perspective. New York: Academic Press.

Treiman, D. J., \& Hartmann, H. I. (1981). Evidence regarding wage differentials. In D. J. Treiman \& H. I. Hartmann (Eds.), Women, work, and wages (pp. 1343). Washington, DC: National Academy Press.
U.S. Bureau of Census. (1994). Current population reports: Series P20, No. 482, Fertility of American women: June 1994. Washington, DC: U.S. Government Printing Office.

U.S. Bureau of Census. (2001). Statistical abstract of the United States: 2001. Washington, DC: U.S. Government Printing Office.

U.S. Department of Health \& Human Services. (1995). Advance report of final marriage statistics, 1989 and 1990. Monthly Vital Statistics Report (Suppl.), 43.

World Bank. (2001). World development indicators 2001. Washington DC: Author. 